\title{
German Health Minister calls time out for $B t$ maize
}

The German government has banned the general release of Novartis Seeds' transgenic $B t$ maize 176 . Reversing a decision by the previous government, the current Health Minister Andrea Fischer instructed the Robert Koch Institute (RKI) on February 16 to revoke a safety license it had previously issued Novartis in January 1997. The move came just a few days before the Bundessortenamt (the Federal Plant Varieties Agency) was expected to approve the $B t$ maize for large-sale planting, and has effectively halted all field trials of the crop. Commentators suggest inter-party wrangling might be to blame, and the government's own advisory committee on biological safety, the Zentrale Kommission für Biologische Sicherheit (ZKBS), says the science behind the decision is not up-to-date. Meanwhile, corn can be added to the growing list of GMOs in limbo while the EU revises its directive $90 / 220$ on the release of GMOs into the environment.

Although a number of projects in Europe have already been caught up in the EU's de facto ban on commercialization of GM plants (Nat. Biotechnol. 18, 139), officials at Novartis seem surprised at the decision. "Only a few days before getting permission, the whole process was very suddenly and unexpectedly stopped," says Rainer Linneweber, spokesman for Novartis Seeds.

There is some speculation that the Ministry of Health's action is the result of wrestling between the two sides of the coalition government, the Greens and the SPD (socialist democratic party). Ecologist Detlef Bartsch from the RWTH-Aachen (Technical University, Aachen) suggests that Green party members, frustrated at losing battles to the SPD-the Greens wanted a freeze on atomic energy, for instance, and were against participation of German troops in the Kosovo war-have focused even more on GMO issues to flex their political muscle.

According to Oliver Rautenberg from biotech communications company BioLinX (Frankfurt), the Minister for the Environment, Jürgen Tritin (a Green party member), had asked the Minister of Agriculture Karl-Heinz Funke (a member of the SPD) to advise the Bundessortenamt not to approve $B t$ maize 176 for large-scale planting. His response became irrelevant, however, when the Minister of Health (a Green party member) stepped in; the structure of responsibilities in the government is such

Ellen Peerenboom is a freelance writer working Halle, Germany. that the only way to ensure non-approval was via the Health Ministry.

Currently, the Bundessortenamt, which comes under the auspices of the Ministry of Agriculture, approves the sale of new plant varieties - on the basis of agricultural criteria, such as resistance to pests. When a new plant is also genetically modified, the RKI, which is overseen by the Ministry of Health, must first approve the plant on the basis of safety. Novartis' Bt maize 176, which is genetically modified to express toxins from

\section{There is some speculation that the health minister's action is the result of wrangling between the two sides of the coalition government, the Greens and the SPD.}

Bacillus thuringiensis, was already declared safe by the RKI over two years ago, in accordance with German law (but under the previous Christian Democratic Union government, in which the Greens were not involved) and the current 90/220 directive. Subsequently, the Bundessortenamt allowed limited seed sales and monitored cultivation on areas smaller than 500 hectares. However, just before Bundessortenamt (under the current coalition government) could approve the maize for large-scale cultivation and sale, the health ministry stepped in, instructing the RKI to withdraw its safety license. This left Novartis no choice but to ask the agency to put its application on hold, so as to avoid an inevitable rejection, which cannot be appealed.

According to Article 16 of the 90/220 directive, each EU member state has the right to deny permission for release of a transgenic organism within its borders on the basis of new scientific knowledge. In support of her decision, the Health Minister referred to a report by the Ökoinstitut (Ecoinstitute; Freiburg), an independent body often cited in opposition to gene technology. The report cites antibiotic resistance genes as an area needing further safety research, and a paper subsequently released by the ministry identifies two additional areas-the effects of $B t$ toxin on nontarget organisms and the effects of $B t$ toxin in the ground. According to the paper, the government's decision is "a call to researchers and industry to further work on the development of responsible uses for gene technology." The government also referred to the actions of Austria and Luxembourg, which rejected Bt 176 Maize in 1997 on the basis of health safety issues concerning antibiotic resistance.

However, some question the scientific credibility of the ministry's claims. "To our knowledge, Bt maize is safe," says ecologist Bartsch, who, like several groups, has been involved with monitoring the release of GMOs in Germany. And Gerd Hobom, chairman of the ZKBS, says "This opinion [the Ökoinstitut report] is based on literature research rather than on scientific research," adding that "It does not reflect the state-of-the-art of scientific knowledge. The question of transferring DNA from the plant to microorganisms is not even discussed in the Ökoinstitut's paper." The ZKBS comprises scientists from different fields, and the German government is required, under Federal law, to take counsel with the ZKBS in any matters regarding GMO safety.

However, in the scramble to prevent approval by the Bundessortenamt, this and other aspects of protocol were overlooked: The Health Minister failed to consult the ZKBS before banning the maize-the ZKBS was only notified after the minister imposed the ban, even though ZKBS members meet with health ministry reps the first Tuesday of every month. (The ZKBS found the Bt maize to be safe with respect to human health in 1997 under the previous CDU government.) Moreover, the RKI was ordered to ban the maize without the opportunity to respond to the Ökoinstitut report, even though it is the RKI, not the Ökoinstitut, that has legal responsibility to assess the safety of GMOs.

Explaining the events, Ulrike Riedel, who is responsible for GMO issues at the Health Ministry, says she would prefer to approve GMOs (if at all) under the much-awaited revised 90/220, which will allow the government to stipulate monitoring studies as a condition of a large-scale license; under the current 90/220, they are voluntary.

The revised directive will require a competent authority to oversee large-scale environmental monitoring, and there are currently four efforts underway-including separate initiatives from the Ministry for the Environment, Ministry for Food, Agriculture, and Forestry, and Ministry of Education and Research-looking at how this might be done.

Meanwhile, Novartis is negotiating with the German government to resume limited risk-assessment field trials.

Ellen Peerenboom 